\title{
Efektivitas Model Pembelajaran SAVI dan REACT Berbantuan LKS terhadap Kemampuan Komunikasi Matematis Siswa SMP
}

\author{
Widya Kusumaningsih ${ }^{1}$, Sutrisno ${ }^{2 *}$, Fiki Hidayah ${ }^{3}$ \\ ${ }_{1,2,3}$ Universitas PGRI Semarang \\ sutrisnojr@upgris.ac.id
}

Diterima: April 2019. Disetujui: Juni 2019. Dipublikasikan: Juli 2019.

\begin{abstract}
ABSTRAK
Penelitian ini bertujuan untuk mengetahui: (1) manakah kemampuan komunikasi matematis yang lebih baik antara siswa yang memperoleh model pembelajaran SAVI berbantuan LKS, model pembelajaran REACT berbantuan LKS, atau model pembelajaran konvensional, (2) apakah kemampuan komunikasi matematis siswa yang memperoleh model pembelajaran SAVI berbantuan LKS dan model pembelajaran REACT berbantuan LKS mencapai ketuntasan klasikal dan individual, dan (3) apakah terdapat pengaruh keaktifan belajar siswa pada model pembelajaran SAVI berbantuan LKS dan model pembelajaran REACT berbantuan LKS terhadap kemampuan komunikasi matematis siswa. Jenis penelitian ini adalah penelitian kuantitatif dengan desain posttest only control design. Populasi dalam penelitian ini adalah siswa SMP Negeri 1 Subah kelas VIII tahun pelajaran 2018/2019. Sampel yang diambil dengan menggunakan cluster random sampling. Teknik pengumpulan data yang digunakan adalah tes dan observasi. Teknik analisis data yang digunakan adalah analisis variansi satu jalan sel tak sama. Hasil penelitian diperoleh bahwa: (1) model pembelajaran SAVI berbantuan LKS dan model pembelajaran REACT berbantuan LKS menghasilkan kemampuan komunikasi matematis yang sama, dan kedua model pembelajaran tersebut menghasilkan kemampuan komunikasi matematis siswa yang lebih baik daripada model pembelajaran konvensional, (2) kemampuan komunikasi matematis siswa yang memperoleh model pembelajaran SAVI berbantuan LKS dan model pembelajaran REACT berbantuan LKS mencapai ketuntasan klasikal dan individual, dan (3) terdapat pengaruh keaktifan belajar siswa pada model pembelajaran SAVI berbantuan LKS dan model pembelajaran REACT berbantuan LKS terhadap kemampuan komunikasi matematis siswa. Model pembelajaran SAVI dan REACT berbantuan LKS dapat digunakan guru untuk meningkatkan kemampuan komunikasi matematis siswa.
\end{abstract}

Kata kunci: kemampuan komunikasi matematis, LKS, REACT, SAVI.

ABSTRACT

This study aims to determine: (1) which mathematical communication skills are better between students who obtain SAVI learning models assisted by LKS, REACT learning models assisted by LKS, or conventional learning models, (2) whether mathematical communication skills of students who get SAVI learning models assisted by LKS and REACT learning models assisted by LKS to achieve classical and individual completeness, and (3) whether there is an influence of student learning activeness on SAVI learning models assisted by LKS and REACT learning models assisted by LKS on students' mathematical communication skills. This type of research is quantitative research with a posttest only control design. The population in this study were students of SMP Negeri 1 Subah class VIII in the academic year 2018/2019. Samples taken using cluster random sampling. Data collection techniques used are tests and observations. The data analysis technique used is the analysis of one-way cell variance is not the same. The results showed that: (1) SAVI learning models assisted by LKS and REACT learning models assisted by LKS produced the same mathematical communication skills, and both learning models produced students' mathematical communication skills better than conventional learning models, (2) ability Mathematical communication of students who obtain SAVI learning models assisted by LKS and REACT learning models assisted by LKS reaches classical and individual completeness, and (3) there is an effect of student learning activeness on SAVI learning models assisted by LKS and REACT learning models assisted by LKS on students' mathematical communication skills. SAVI and REACT learning models assisted by LKS can be used by teachers to improve students' mathematical communication skills.

Keywords: Mathematical Communication Ability,LKS, REACT, SAVI.

How to Cite: Kusumaningsih, W., Sutrisno, S., \& Hidayah, F. (2019). Efektivitas Model Pembelajaran SAVI dan REACT Berbantuan LKS terhadap Kemampuan Komunikasi Matematis Siswa SMP. Journal Of Medives : Journal Of Mathematics Education IKIP Veteran Semarang, 3(2), 197-206. 


\section{PENDAHULUAN}

Komunikasi matematis yaitu suatu cara siswa untuk mengungkapkan ideide matematis baik secara lisan, tertulis, gambar, diagram, menggunakan benda, menyajikan dalam bentuk aljabar, atau menggunakan simbol matematika (Agustyaningrum, 2011). Kemampuan komunikasi matematis (mathematical communication) dalam pembelajaran matematika sangat perlu untuk dikembangkan. Hal ini karena melalui komunikasi matematis siswa dapat mengorganisasikan berpikir matematisnya baik secara lisan maupun tulisan sehingga dapat membantu dalam membangun gagasan (Ramadhan \& Minarti, 2018).

Namun kenyataannya, data dari Trends in International Mathematics and Science Study (TIMSS) tahun 2015 menunjukkan bahwa penekanan pembelajaran matematika di Indonesia lebih banyak pada penguasaan keterampilan dasar, hanya sedikit sekali penekanan penerapan matematika dalam konteks kehidupan sehari-hari dan berkomunikasi secara matematis. (Umar, 2012) menyatakan bahwa komunikasi matematika pada pembelajaran matematika sangat perlu untuk dikembangkan. Komunikasi matematika memilki peran penting dalam pembelajaran matematika, sebab melalui komunikasi matematika siswa dapat mengorganisasikan dan mengkonsolidasikan pemikiran matematis mereka.

Beberapa model pembelajaran yang diharapkan dapat meningkatkan kemampuan komunikasi matematis dan keaktifan siswa dalam pembelajaran adalah model pembelajaran SAVI
(Somatic, Auditory, Visualization, dan Intellectualy) dan REACT (Relating, Experiencing, Applying, Cooperating, dan Transferring). Menurut Sutrisno, Mardiyana, \& Usodo (2013), pembelajaran SAVI merupakan pembelajaran dengan menggabungkan gerakan fisik dan aktifitas intelektual serta melibatkan semua indera yang berpengaruh besar dalam pembelajaran. Pembelajaran ini didesain secara alamiah untuk menyelaraskan suasana pembelajaran dengan instruksi khusus berdasarkan kebutuhan saat proses pembelajaran tanpa mengesampingkan aspek privasi siswa. Sebagai calon pendidik matematika perlu meyadari pentingnya kemampuan komunikasi karena masalah sebagian besar untuk kemampuan komunikasi yang efektif (Nayazik \& Wahyuni, 2017).

Menurut Meier (2000), SAVI dapat direncanakan dalam empat tahap yaitu (1) tahap persiapan, pada tahap ini guru membangkitkan minat siswa dan menempatkan mereka dalam situasi optimal untuk belajar, (2) tahap penyampaian pada tahap ini siswa dibantu oleh guru menemukan materi belajar yang baru dengan cara menyenangkan, relevan, melibatkan panca indera, dan cocok untuk semua gaya belajar, (3) tahap praktik siswa mengintegrasikan dan menyerap pengetahuan dan ketrampilan baru dengan berbagai cara, (4) tahap penampilan hasil, pada tahap ini siswa menerapkan dan memperluas pengetahuan atau keterampilan baru mereka pada pekerjaan sehingga hasil belajar akan melekat dan penampilan hasil akan terus meningkat. 
Model pembelajaran REACT menekankan pada pemberian informasi yang berkaitan dengan informasi yang sebelumnya telah diketahuai oleh siswa, sehingga siswa akan lebih mudah memahami konsep-konsep yang disampaikan oleh guru karena sering dijumpai dalam kehidupan sehari-hari. Menurut Crawford (2001) komponen dan langkah-langkah pembelajaran REACT yaitu (1) Relating, pemberian pertanyaan yang dapat dijawab siswa dari pengalamannya diluar kelas; (2) Experiencing, siswa menghubungkan informasi baru dengan berbagai pengalaman/pengetahuan sebelumnya sehingga dapat menyusun pengetahuan baru; (3) Applying, siswa belajar untuk menerapkan konsep dalam aktivitas pemecahan masalah; (4) Cooperating, bekerjasama dengan kelompok untuk menyelesaikan permasalahan dan saling sharing kepada teman lainnya; (5) Transferring, siswa diarahkan untuk menggunakan pengetahuan ke dalam konteks/situasi yang baru.

Untuk menerapkan beberapa model pembelajaran tersebut, perlu didukung pula dengan media pembelajaran yang tepat. Menurut Purbasari, Kahfi, \& Yunus (2013) penggunaan media dalam proses pembelajaran bertujuan agar proses pembelajaran dapat berlangsung secara tepat guna dan berdaya guna sehingga mutu pendidikan dapat ditingkatkan. Salah satu media pembelajaran yang dapat digunakan adalah Lembar Kerja Siswa (LKS). Menurut Hamdani (2011) Lembar Kerja Siswa (LKS) merupakan salah satu alat bantu pembelajaran. Secara umum LKS merupakan perangkat pembelajaran sebagai pelengkap atau sarana pendukung pelaksanaan Rencana Pembelajaran. LKS sangat berperan pada rekonstruksi pengetahuan siswa ketika siswa terlibat diskusi. LKS dapat menuntun siswa dalam memahami materi pembelajaran, sehingga siswa menguasai materi pembelajaran dan memiliki komunikasi matematis yang baik.

Berdasarkan uraian di atas, maka tujuan dari penelitian ini adalah untuk mengetahui: (1) manakah kemampuan komunikasi matematis yang lebih baik antara siswa yang memperoleh model pembelajaran SAVI berbantuan LKS, model pembelajaran REACT berbantuan LKS, atau model pembelajaran konvensional, (2) apakah kemampuan komunikasi matematis siswa yang memperoleh model pembelajaran SAVI berbantuan LKS dan model pembelajaran REACT berbantuan LKS mencapai ketuntasan klasikal dan individual, dan (3) apakah terdapat pengaruh keaktifan belajar siswa pada model pembelajaran SAVI berbantuan LKS dan model pembelajaran REACT berbantuan LKS terhadap kemampuan komunikasi matematis siswa.

\section{METODE PENELITIAN}

Penelitian ini dilaksanakan di SMP Negeri 1 Subah. Jenis penelitian ini adalah penelitian kuantitatif dengan desain posttest only control design. Populasi dalam penelitian ini adalah siswa SMP Negeri 1 Subah kelas VIII semester ganjil tahun pelajaran 2018/2019. Sampel yang diambil adalah kelas VIII B, VIII C, dan VIII F dengan menggunakan teknik cluster random 
sampling. Sampel pada penelitian ini meliputi 92 siswa yang terdiri dari 34 siswa kelas eksperimen 1 (VIII F), 30 siswa kelas eksperimen 2 (VIII C), dan 28 siswa kelas kontrol (VIII B). Ketiga sampel tersebut juga sudah dilakukan uji keseimbangan untuk memastikan bahwa ketiga sampel memiliki kemampuan awal yang sama sebelum diberikan perlakuan, sehingga segala perubahan yang terjadi setelah perlakuan dapat dikaitkan dengan perlakuan yang diberikan. Data kemampuan awal yang dimaksud adalah data nilai ulangan harian pada materi sebelumnya.

Teknik pengumpulan data yang dilakukan adalah tes dan observasi. Teknik tes digunakan untuk mengukur kemampuan komunikasi matematis siswa setelah diberikan perlakuan. Tes yang disusun terdiri dari 7 butir soal dengan materi pola bilangan. Indikator yang digunakan sebagai pedoman penyusunan tes kemampuan komunikasi sesuai pendapat Sumarmo (2006), yaitu (a) menyatakan benda-benda nyata, situasi, dan peristiwa sehari-hari kedalam bentuk model matematika, (b) menjelaskan ide dan model matematika ke dalam bahasa biasa, (c) mendengarkan, berdiskusi, dan menulis tentang matematika, (d) membaca dengan pemahaman suatu presentasi matematika tertulis, (e) membuat konjektur (dugaan), menyusun argumen, dan membuat generalisasi. Namun, pada penelitian ini, indikator (c) dan (e) tidak digunakan dalam tes karena indikator tersebut tidak dapat diukur secara langsung melalui tes tertulis, sehingga indikator yang digunakan untuk menyusun soal adalah indikator (a), (b), dan (d). Sedangkan teknik observasi digunakan untuk mengumpulkan data aktivitas belajar siswa pada saat pembelajaran di kelas.

\section{HASIL DAN PEMBAHASAN}

Setelah diberi perlakuan, dilakuan tes akhir terhadap ketiga sampel tersebut. Data yang diperoleh dari tes tersebut dan hasil observasi selama proses pembelajaran digunakan sebagai data akhirpenelitian. Teknis analisis yang digunakan meliputi Analisis variansi (Anava), uji ketuntasan belajar, dan uji regresi.

\section{Uji Persyaratan Anava}

Berdasarkan uji normalitas distribusi, baik kelas eksperimen 1, kelas eksperimen 2 maupun kelas kontrol berasal dari populasi yang berdistribusi normal. Selain itu, berdasarkan hasil uji homogenitas variansi didapatkan $\chi_{\text {hitung }}^{2}=2,246$. Karena $\chi_{\text {hitung }}^{2}=$ $2,246<\chi_{\text {tabel }}^{2}=5,99$ sehingga dapat disimpulkan hipotesis $\mathrm{H}_{0}$ diterima. Artinya, ketiga kelas sampel tersebut mempunyai varians yang sama (homogen).

\section{Uji Anava}

Semua uji persyaratan Anava telah terpenuhi, sehingga dapat dilakukan Anava. Tabel 1 menunjukkan rangkuman Anava.

Tabel 1. Hasil Uji Anava Data Akhir

\begin{tabular}{ccccc}
\hline Sumber Variasi & dk & JK & KT & F \\
& & & & \\
\hline Rata-rata & 1 & 477054 & 477054 & \\
Antar kelompok & 2 & 1075,92 & 537,958 & 6,305 \\
Dalam Kelompok & 89 & 7593 & 85,312 & \\
Total & 92 & 485723 & & \\
\hline
\end{tabular}


Berdasarkan Tabel 1, didapatkan $\mathrm{F}_{\text {hitung }}=6,305>\mathrm{F}_{\text {tabel }}=3,099$ maka $\mathrm{H}_{0}$ ditolak. Jadi dapat disimpulkan bahwa terdapat perbedaan rata-rata kemampuan komunikasi matematis siswa pada kelas eksperimen 1, kelas eksperimen 2, dan kelas kontrol setelah diberi perlakuan. Oleh karena itu, dapat disimpulkan bahwa terdapat perbedaan kemampuan komunikasi matematis siswa yang mendapat perlakuan model pembelajaran SAVI berbantu LKS, model pembelajaran REACT berbantu LKS dan model pembelajaran konvensional maka selanjutnya dilakukan uji scheffe'.

\section{Uji Scheffe'}

Uji scheffe' dilakukan guna untuk mengetahui model pembelajaran mana yang mempunyai perbedaan.

Tabel 2. Hasil Uji Scheffe'

\begin{tabular}{|c|c|c|c|}
\hline$F_{i-j}$ & $F_{\text {hitung }}$ & $F_{\text {tabel }}$ & Keputusan \\
\hline$\overline{F_{1-2}}$ & 0,185 & & $\mathrm{H}_{0}$ diterima \\
\hline$F_{2-3}$ & 10,923 & 6,198 & $\mathrm{H}_{0}$ ditolak \\
\hline$F_{1-2}$ & 8,885 & & $\mathrm{H}_{0}$ ditolak \\
\hline
\end{tabular}

Berdasarkan Tabel 2 diperoleh bahwa dk $=\left\{\mathrm{F} \mid \mathrm{F}>2 \mathrm{~F}_{0,05 ; 2,89}\right\}=\{\mathrm{F} \mid \mathrm{F}$ $>6,198\}$. Berdasarkan penjelasan di atas dapat diperoleh kesimpulan (1) tidak ada perbedaan model pembelajaran SAVI berbantuan LKS dan model pembelajaran REACT berbantuan LKS terhadap kemampuan komunikasi matematis SMP, (2) ada perbedaan model pembelajaran REACT berbantuan LKS dengan model pembelajaran konvensional terhadap kemampuan komunikasi matematis SMP dan rerata model pembelajaran REACT lebih tinggi dari rerata model pembelajaran konvensional yaitu $75>67$ maka model pembelajaran
REACT berbantuan LKS lebih baik daripada model pembelajaran konvensional, (3) ada perbedaan model pembelajaran SAVI berbantuan LKS dengan model pembelajaran konvensional terhadap kemampuan komunikasi matematis SMP dan rerata model pembelajaran SAVI lebih tinggi dari rerata model pembelajaran konvensional yaitu $74>67$ maka model pembelajaran SAVI berbantuan LKS lebih baik dari pada model pembelajaran konvensional.

\section{Ketuntasan Belajar}

Ketuntasan belajar individual ditandai dengan pencapaian nilai tes pada pembelajaran dengan menggunakan model SAVI berbantuan LKS dan model REACT berbantuan LKS sesuai dengan kriteria ketuntasan minimal (KKM) disekolah yaitu 67. Suatu kelas dikatakan telah mencapai ketuntasan belajar klasikal jika banyaknya siswa yang telah mencapai ketuntasan belajar klasikal sekurang-kurangnya adalah $80 \%$. Ketuntasan belajar individual dari hasil tes belajar kelas eksperimen 1 untuk ketuntasan komunikasi matematis yang terdiri dari 34 siswa terdapat 31 siswa tuntas dan 3 siswa tidak tuntas. Untuk ketuntasan komunikasi matematis kelas eksperimen 2 yang terdiri dari 30 siswa terdapat 28 siswa tuntas dan 2 siswa tidak tuntas. Presentase ketuntasan belajar klasikal kelas eksperimen 1 pada komunikasi matematis sebesar $91,18 \%$ dan kelas eksperimen 2 sebesar 93,33\%, maka dapat diperoleh bahwa kemampuan komunikasi matematis antara siswa SMP yang memperoleh model pembelajaran SAVI berbantuan LKS dan model pembelajaran REACT 
berbantuan LKS mencapai tuntas secara klasikal dan individual.

\section{Uji Regresi Linear Sederhana}

Uji regresi linear sederhana yang digunakan untuk mendapatkan pengaruh keaktifan terhadap kemampuan komunikasi matematis siswa SMP pada pembelajaran menggunakan model pembelajaran SAVI berbantuan LKS dan REACT berbantuan LKS. Hasil analisis akhir pada kelas eksperimen I diperoleh bahwa persamaan regresi linear yaitu $\widehat{Y}=40,3853+0,5446 X$ dan untuk kelas eksperimen 2 diperoleh persamaan regresi linear yaitu $\hat{Y}=23,2078+$ $0,8838 X$.

Uji keberartian regresi linear untuk kelas eksperimen 1 diperoleh $F_{\text {hitung }}=$ $7,6739>\mathrm{F}_{\text {tabel }}=4,15$ maka dapat disimpulkan bahwa $\mathrm{H}_{0}$ ditolak. Sedangkan untuk kelas eksperimen 2 diperoleh $=7,6739>\mathrm{F}_{\text {tabel }}=4,20$ maka dapat disimpulkan bahwa $\mathrm{H}_{0}$ ditolak. Karena keputusan eksperimen 1 dan eksperimen $2 \mathrm{H}_{0}$ ditolak, hal ini berarti bahwa hubungan linear $\mathrm{X}$ dan $\mathrm{Y}$ berarti. Untuk uji keberartian koefisien regresi linear sederhana kelas eksperimen 1 diperoleh $t_{\text {hitung }}=2,7702>t_{\text {tabel }}=2,0369$ maka dapat disimpulkan bahwa $\mathrm{H}_{0}$ ditolak. Dapat disimpulkan bahwa koefisien $\beta$ berarti. Artinya ada pengaruh antara variabel keaktifan terhadap kemampuan komunikasi matematis siswa, dan karena $b=0,5446$ bernilai positif, maka terdapat pengaruh positif antara keaktifan terhadap kemampuan komunikasi matematis siswa. Selain itu diperoleh juga $r^{2}=$ 0,1934 dengan presentase $19,34 \%$. Jadi pengaruh positif antara keaktifan terhadap kemampuan komunikasi matematis siswa sebesar 19,34\%. Artinya kemampuan komunikasi matematis siswa 19,34\% ditentukan oleh keaktifan, sisanya ditentukan oleh faktor lain. Sedangkan untuk uji keberartian koefisien regresi linear sederhana kelas eksperimen 2 diperoleh $t_{\text {hitung }}=5,2573>$ $\mathrm{t}_{\text {tabel }}=2,0484$ maka dapat disimpulkan bahwa $\mathrm{H}_{0}$ ditolak. Dapat disimpulkan bahwa koefisien $\beta$ berarti. Artinya ada pengaruh antara variabel keaktifan terhadap kemampuan komunikasi matematis siswa, dan karena $b=0,8838$ bernilai positif, maka terdapat pengaruh positif antara keaktifan terhadap kemampuan komunikasi matematis siswa. Selain itu diperoleh juga $\mathrm{r}^{2}=$ 0,4968 dengan presentase $49,68 \%$. Jadi pengaruh positif antara keaktifan terhadap kemampuan komunikasi matematis siswa sebesar 49,68\%. Artinya kemampuan komunikasi matematis siswa 49,68\% ditentukan oleh keaktifan, sisanya ditentukan oleh faktor lain.

Hal tersebut dikarenakan dalam penerapan model pembelajaran SAVI tidak sekadar siswa paham akan materi yang diajarkan, tetapi belajar haruslah menggunakan kemampuan berpikir (minds-on) belajar haruslah dengan konsentrasi pikiran dan berlatih menggunakannya melalui bernalar, menyelidiki, mengidentifikasi, menemukan, mencipta, mengkontruksi, memecahkan masalah dan menerapkannya (Shoimin, 2014). Sedangkan pada model pembelajaran REACT dapat membuat siswa menemukan sendiri rumus/konsep atau memahami konsep yang telah diberikan dengan bekerjasama antar 
siswa dan bisa menerapkan ilmu yang diperoleh ke kehidupan nyata dan mentransfernya dalam konteks yang baru (Crawford, 2001).

Saat pembelajaran berlangsung siswa sangat tertarik dan antusias mengikuti pembelajaran karena menggunkan alat bantu berupa LKS yang sebelumnya belum pernah mereka dapatkan, mereka merasa mendapatkan pembelajaran yang berbeda dari sebelumnya yang hanya mencatat dan mendengarkan materi yang disampaikan, dan mereka sangat terbantu dalam memahami materi sehingga menambah keaktifan siswa. Dengan media LKS ini siswa dapat meningkatkan aktivitas belajar, mendorong siswa mampu bekerja sendiri, dan membimbing siswa secara baik kearah pengembangan konsep.

Berikut adalah analisis pengerjaan soal melalui lembar jawab siswa.

\section{Indikator 1 (Soal Nomor 3)}

Anton mencoba membuat sebuah menara yang disusun dari lidi. Gambar 1 adalah susunan menara lidi yang dibuat oleh Anton.

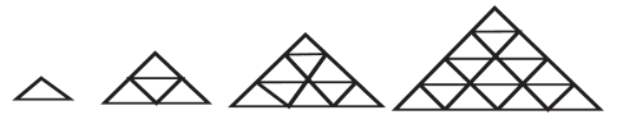

(1) (2) (3) (4)

\section{Gambar 1. Soal Nomor 3}

Hitunglah banyaknya lidi pada masing-masing gambar segitiga di atas! Tentukan barisan bilangannya!

$$
\text { (3) } 3,9,18,30
$$

Gambar 2. Jawaban Siswa Skor 3
Dari jawaban siswa terlihat bahwa siswa dapat menjelaskan situasi kedalam bentuk model matematika. Pada soal nomor 3, siswa dapat menyatakan susunan menara lidi ke bentuk barisan bilangan dengan benar. Sehingga siswa tersebut dapat dikatakan telah memenuhi indikator 1.

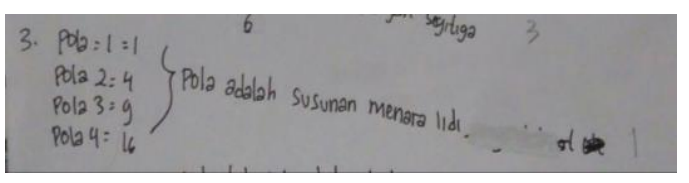

Gambar 3. Jawaban Siswa Skor 1

Dari jawaban siswa terlihat bahwa soal nomor 3, siswa salah menyatakan susunan menara lidi ke dalam barisan bilangan. Siswa sudah banyak yang memahami maksud soal dan pertanyaan soal, tetapi ada beberapa yang kurang memahami soal, sehingga terjadi kesalahan. Hal ini sejalan dengan penelitian yang dilakukan oleh Sepeng \& Madzorera (2014) menyebutkan bahwa kendala yang dialami oleh siswa dalam menyelesaikan masalah adalah dalam memahami bahasa dalam soal, ketidakmampuan siswa dalam memahami bahasa yang ada dalam soal akan menyebabkan siswa gagal dalam memperoleh jawaban yang benar.

\section{Indikator 2 (Soal Nomor 4)}

Perhatikan gambar berikut!

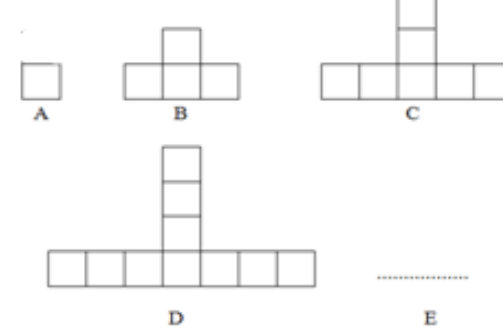

Gambar 4. Soal Nomor 4 
Berdasarkan pola gambar di atas, bagaimana bentuk pola bilangan huruf E! Tulislah langkah-langkahnya!

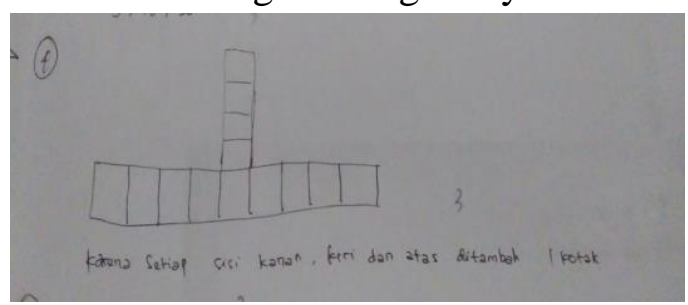

Gambar 5. Jawaban Siswa Skor 3

Dari jawaban siswa terlihat bahwa siswa dapat menjelaskan ide dan model matematika kedalam bahasa biasa. Pada soal nomor 4, terlihat bahwa siswa dapat menjelaskan bagaimana cara menggambarkan pola bilangan huruf E dengan benar dan dapat menuliskannya kedalam bahasanya sendiri dengan benar. Sehingga pada jawaban ini siswa sudah memenuhi indikator 2 .

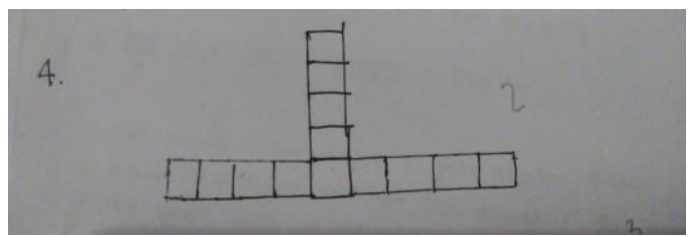

Gambar 6. Jawaban Siswa Skor 2

Dari jawaban siswa terlihat bahwa siswa kurang dapat menjelaskan ide dan model matematika kedalam bahasa biasa. Pada soal nomor 4 terlihat bahwa siswa dapat menggambarkan pola bilangan huruf $\mathrm{E}$ dengan benar tetapi siswa belum dapat menuliskan bagaimana cara mendapatkan pola bilangan huruf $\mathrm{E}$ dengan bahasanya sendiri.

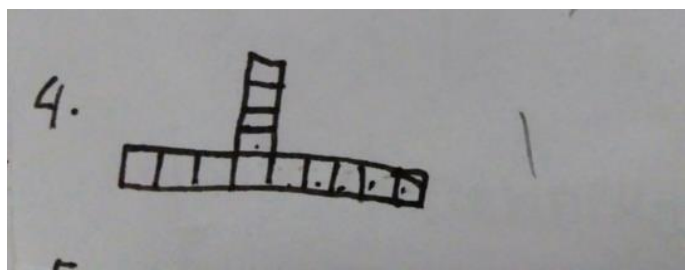

Gambar 7. Jawaban Siswa Skor 1
Dari jawaban siswa terlihat bahwa siswa belum dapat menjelaskan ide dan model matematika kedalam bahasa biasa. Pada nomor 4 terlihat bahwa siswa belum dapat menggambarkan pola bilangan huruf $\mathrm{E}$ dengan benar dan belum dapat menuliskannya kedalam bahasanya sendiri. Hal ini sejalan dengan yang dikatakan oleh Nurussafa'at, Sujadi, \& Riyadi (2016) yang menyebutkan kesalahan bahasa yang dilakukan oleh siswa dalam menyelesaikan soal adalah siswa tidak bisa menuliskan apa yang diketahui dan yang ditanyakan dalam soal, sehingga menyebabkan siswa bingung dalam menyelesaikan masalah.

\section{Indikator 3 (Soal Nomor 6)}

OSIS suatu sekolah mengadakan pentas seni untuk amal yang terbuka untuk masyarakat umum. Hasil penjualan tiket acara tersebut akan disumbangkan untuk korban bencana alam. Panitia memilih tempat berupa gedung pertunjukan yang tempat duduk penontonnya berbentuk sektor lingkaran terdiri dari enam baris.

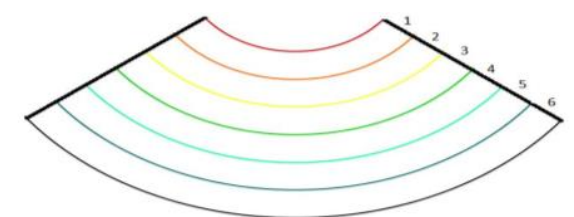

Gambar 8. Soal Nomor 6

Banyaknya kursi penonton pada masing-masing baris membentuk pola barisan tertentu. Jika pada baris pertama terdapat 25 kursi, baris kedua 35 kursi, baris ketiga 50 kursi, dan seterusnya. Tentukanlah barisan bilangan yang terbentuk dan tentukan banyaknya seluruh tempat duduk pada gedung 
pertunjukan itu. Tulislah langkah penyelesaiannya!

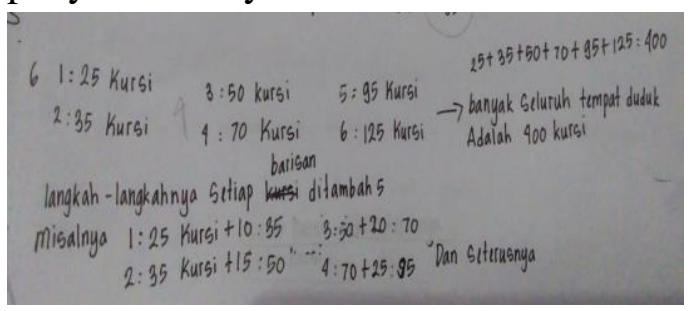

Gambar 9. Jawaban Siswa Skor 4

Dari jawaban siswa terlihat bahwa siswa dapat membaca dengan pemahaman suatu presentasi matematika tertulis. Pada soal nomor 6, terlihat bahwa siswa dapat menuliskan barisan bilangan dengan lengkap dan mententukan banyaknya seluruh tempat duduk pada gedung pertunjukkan pentas seni dengan benar.

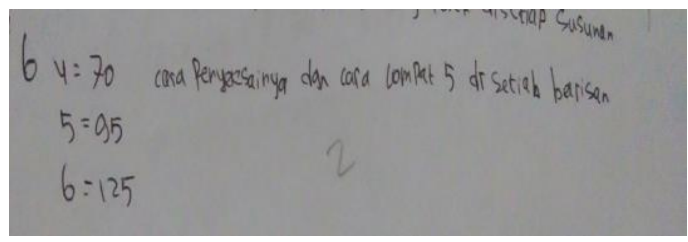

Gambar 10. Jawaban Siswa Skor 2

Dari jawaban siswa terlihat bahwa siswa kurang dapat membaca dengan pemahaman suatu presentasi matematika tertulis. Pada soal nomer 6, terlihat bahwa siswa masih kurang paham dengan soal yang diberikan. Siswa hanya dapat menuliskan barisan bilangannya saja, dan belum dapat menentukan jumlah seluruh kursi yang ada di pertunjukkan pentas seni. Hal ini sejalan dengan penelitian yang dilakukan Windari (2014) mengatakan siswa telah menguasai konsep yang harus digunakan untuk menyelesaikan soal, kebanyakan dari mereka masih banyak yang ceroboh dalam menyelesaikan soal itu.

\section{KESIMPULAN}

Dari penelitian ini diperoleh simpulan bahwa model pembelajaran SAVI berbantuan LKS dan model pembelajaran REACT berbantuan LKS menghasilkan kemampuan komunikasi matematis yang sama, dan kedua model pembelajaran tersebut menghasilkan kemampuan komunikasi matematis siswa yang lebih baik daripada model pembelajaran konvensional. Selain itu, kemampuan komunikasi matematis siswa yang memperoleh model pembelajaran SAVI berbantuan LKS dan model pembelajaran REACT berbantuan LKS mencapai ketuntasan klasikal dan individual. Hasil penelitian juga menunjukkan adanya pengaruh keaktifan belajar siswa pada model pembelajaran SAVI berbantuan LKS dan model pembelajaran REACT berbantuan LKS terhadap kemampuan komunikasi matematis siswa. Model pembelajaran SAVI dan REACT berbantuan LKS dapat digunakan guru untuk meningkatkan kemampuan komunikasi matematis siswa.

\section{DAFTAR PUSTAKA}

Agustyaningrum, N. (2011, December 3). Implementasi Model Pembelajaran Learning Cycle $5 E \quad$ Untuk Meningkatkan Kemampuan Komunikasi Matematis Siswa Kelas IX B SMP Negeri 2 Sleman. 377-387. Yogyakarta: FMIPA UNY.

Crawford, M. L. (2001). Teaching Contextually: Research, Rational, and Techniques for Improving Student Motivation and Achievment in Mathematics Science. Waco, Texas, USA: CORD CCI Publishing, Inc. 
Hamdani. (2011). Strategi Belajar Mengajar. Bandung: Pustaka Setia.

Meier, D. (2000). The Accelerated Learning Handbook: A Creative Guide to Designing and Delivering Faster, More Effective Training Programs. McGraw Hill Professional.

Nayazik, A., \& Wahyuni, A. (2017). Peningkatan Kemampuan Komunikasi Matematis Model Ideal Problem Solving dalam Aspek Grammatical dan Sosiolinguistik. Jurnal Didaktik Matematika, 4(2), 107-114. https://doi.org/10.24815/jdm.v4i 2.8461

Nurussafa'at, F. A., Sujadi, I., \& Riyadi, R. (2016). Analisis Kesalahan Siswa dalam Menyelesaikan soal Cerita pada Materi Volume Prisma dengan Fong's Shcematic Model for Error Analysis Ditinjau dari Gaya Kognitif Siswa. Jurnal Pembelajaran Matematika, 4(2).

Purbasari, R. J., Kahfi, M. S., \& Yunus, M. (2013). Pengembangan Aplikasi Android sebagai Media Pembelajaran Matematika pada Materi Dimensi Tiga untuk Siswa SMA Kelas X. Jurnal Online Universitas Negeri Malang, 1(4), 1-10.

Ramadhan, I., \& Minarti, E. D. (2018). Analisis

Kemampuan

Komunikasi Matematis Siswa SMP dalam Menyelesaikan Soal Lingkaran. Journal of Medives: Journal of Mathematics Education IKIP Veteran Semarang, 2(2), 151-161.

Sepeng, P., \& Madzorera, A. (2014). Sources of Difficulty in
Comprehending and Solving Mathematical Word Problems. International Journal of Educational Sciences, 6(2), 217225.

Shoimin, A. (2014). Model Pembelajaran Inovatif dalam Kurikulum 2013. Yogyakarta: Ar-Ruzz Media.

Sumarmo, U. (2006). Pembelajaran Keterampilan Membaca Matematika pada Siswa Sekolah Menengah. Bandung: Universitas Pendidikan Indonesia.

Sutrisno, S., Mardiyana, M., \& Usodo, B. (2013). Eksperimentasi Model Pembelajaran Kooperatif Tipe STAD dan TPS Dengan Pendekatan Savi Terhadap Prestasi dan Motivasi Belajar Ditinjau Dari Gaya Belajar Siswa. Jurnal Pembelajaran Matematika, 1(7).

Umar, W. (2012). Membangun Kemampuan Komunikasi Matematis dalam Pembelajaran Matematika. Infinity Journal, 1(1), 1-9.

Windari, F. (2014). Meningkatkan Kemampuan Pemecahan Masalah Matematika Siswa Kelas VIII SMPN 8 Padang Tahun Pelajaran 2013/2014 dengan Menggunakan Strategi Pembelajaran Inkuiri. Jurnal Pendidikan Matematika, 3(2). 